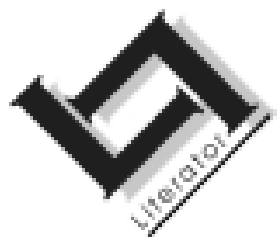

\title{
Spore in die sand - 'n herbeskouing van die oeuvre van C.M. van den Heever
}

\author{
Heilna du Plooy \\ Skool vir Tale \\ Afrikaans en Nederlands \\ Potchefstroomse Universiteit vir $\mathrm{CHO}$ \\ POTCHEFSTROOM \\ E-pos:afnhjgdp@puknet.puk.ac.za
}

\section{Abstract}

Footprints in the sand - a re-evaluation of C.M. van den Heever's oeuvre C.M. van den Heever was a prominent Afrikaans writer in the period between 1930 and 1950. Since the 1960s the general opinion held by literary scholars has been that his work has become dated thematically as well as stylistically. In an essay, written in 1947, Van den Heever states and explains his poetical stance on some key issues such as the sources of his writing, the schism between romanticism and realism in his life and work, the importance of a vision of life in his work. The essay also contains some valuable indications of the philosophical influences on Van den Heever as a person and as a writer. In this article Van den Heever's own views are compared to the views held by critics. The article indicates that Van den Heever consciously addressed exactly those problems that critics regard as shortcomings in his oeuvre. The article concludes that rereading older works of literature opens up new perspectives on the past and on older literary texts. Older literature also adds to the present because knowledge of the past contributes to an understanding of the present. In the final instance the statement is made that literature constitutes a link between past and present, and older literature lives on through rereadings by committed readers.

Opsomming

Spore in die sand - 'n herbeskouing van die oeuvre van C.M. van den Heever

C.M. van den Heever was 'n toonaangewende skrywer tussen 1930 en 1950. Vanaf $1960 \mathrm{kry}$ sy werk min aandag aangesien dit stilisties sowel as tematies nie meer die impak van vroeër het nie en selfs as verouderd 
beskou word. In 'n essay, gepubliseer in 1947, stel en verduidelik Van den Heever belangrike opvattings oor sy eie werk. Hy praat oor die bronne waaruit sy skryfwerk groei, die dualiteit tussen realisme en romantiek in sy werk en die belangrikheid van 'n etiese ingesteldheid in alle estetiese werk. Die essay bevat ook waardevolle inligting oor die filosofiese invloede op Van den Heever as mens en op sy werk. In hierdie artikel word Van den Heever se eie siening van sy werk sowel as sy poëtikale opvattings in verband gebring met die beskouings en oordele van literatore en kritici. Daar word aangetoon dat Van den Heever bewus was van die aard en styl van sy werk en dat hy bewustelik met hierdie kwessies in interaksie getree het. Die gevolgtrekking word gemaak dat die herlees van ouer tekste telkens 'n nuwe perspektief op die werke teweegbring, sowel op die tekste self as op die periode waarin dit geskryf is. Ouer literatuur verryk die hede omdat begrip van die verlede meewerk om die hede te verstaan. Die artikel sluit af met die gedagte dat literatuur 'n band tussen hede en verlede daarstel en dat ouer literêre tekste bly "lewe" in die herlesings van toegewyde lesers.

\section{Inleiding}

Die laaste wysheidsgedagte wat C.M. van den Heever in Boek Een in Woestynsand dek die spore uitspreek, lui soos volg:

Die groot beweging van die lewe neem ons egter genadeloos mee en mens, groep, nasie en groot beskawings word uiteindelik toegewaai, en selfs die tekens van hulle verlange na blywendheid word uitgewis (Van den Heever, 1946:79).

As hierdie opvatting van die skrywer oor die nietigheid en verganklikheid van sowel die individu as magtige ryke in die werklikheid reg is, as dit onvermydelik is dat die mens se plek en nalatenskap in die voortgang van die geskiedenis inderdaad onder die sand van die tyd toegewaai word, wat sou 'n mens dan kon sê oor die uitwerking en nawerking van iets so abstrak soos die woorde van 'n skrywer? Wat word van die skrywer se boeke, van die romans en verhale en verse nadat hy self nie meer daar is nie, wanneer daar twee of meer generasies oor sy werk heengegaan het? Is daar enige korrelasie tussen die manier waarop die geskiedenis met die skrywer se werk omgaan en hoe dit in sy eie tyd aangeslaan is? Wat word van die skrywer se siening van sy skrywerskap en wat word van die idees en gedagtes wat hy in sy boeke neerskryf? Watter uitwerking het dit op 'n skrywer dat hy weet dat sommige skrywers groter geag word namate die tyd verbygaan en dat ander verdwyn of agteruit geskuif word?

Uitgaande van hierdie vrae sou 'n mens C.M. van den Heever se nalatenskap kon bedink. In hierdie artikel word dit gedoen deur kortliks te 
kyk na Van den Heever se plek in die literatuurgeskiedenis en daarna die menings oor sy werk te vergelyk met sy eie siening daarvan. Die vraag is hoe die waarde van 'n skrywer se werk na vyftig jaar beskou kan word en watter rol die aard en tematiek van die werk en die tydsgebondenheid van styl hierin 'n rol speel. Die interessante wat uit die ondersoek na vore gekom het, is hoe Van den Heever se eie uitsprake oor sy werk korreleer met wat die kritiek daaroor te sê gehad het. In die lig hiervan moet 'n mens vra of bepaalde negatiewe oordele nie juis weer beoordeel moet word nie, spesifiek met inagneming van die samehang tussen die skrywer se poëtikale opvattings en die tematiek in sy oeuvre.

\section{Literêr-historiese plasing}

C.M. van den Heever se vroeë poësie sluit aan by die werk van die ouer digters soos Leipoldt, Celliers en Malherbe, maar die bundel Deining (1932) word deur Opperman (1953:140) as die eerste bundel van Dertig beskou. As sodanig was dit 'n belangrike bundel en C.M. van den Heever se reputasie as een van die vroegste figure van Dertig word verder bevestig deur die bundel Aardse vlam (1938) waarvoor hy ook die Hertzog-prys kry (Opperman, 1953:145). Hierna wy Van den Heever sy kragte hoofsaaklik aan die prosa en hy word een van die belangrikste prosaskrywers van die dertiger- en veertigerjare in Afrikaans. Al word die belang van sy poësie deurgaans erken (Opperman, 1953:121-159; Dekker, 1960:199), het Van den Heever later veral vir sy prosawerk bekend geword (Van Coller, 1987:41). Hy was 'n baie produktiewe prosaskrywer en die bekendste prosawerke soos Somer (1935) en Laat Vrugte (1938) het oor die jare belangrike werke in die Afrikaanse literêre kanon gebly (Kannemeyer, 1978:310; Du Plooy, 1999:654, 659). Die agting vir Van den Heever se werk en die belang van sy plek in die Afrikaanse literêre wêreld in die laat veertiger- en vroeë vyftigerjare blyk uit die bibliografie wat deur Yvonne Kamp opgestel is (Kamp, 1953).

C.M. van den Heever se werk het met verloop van tyd op die agtergrond geraak, veral omdat nuwe en sterker prosaskrywers vanaf die middelvyftigerjare begin publiseer het, in 'n nuwe golf wat ontwikkel tot die invloedryke beweging van Sestig. Vandag word Van den Heever se werk steeds gelees en bestudeer op hoërskoolvlak en in universiteitskursusse, maar op beperkte skaal. Afgesien van die paar gedigte in Groot Verseboek wat hopelik nog onder oë geneem word, word daar hoofsaaklik gekonsentreer op prosawerke soos Somer (1935) en Laat Vrugte (1987 [1939]), veral aangesien hierdie romans uitnemende voorbeelde is van die plaasroman wat as genre steeds (al is dit in geparodieerde vorm) 'n belangrike plek beklee in die Afrikaanse romankuns. 
Dit is egter 'n vraag of C.M. van den Heever nog aktief gelees word en of gewone lesers nog sy werk lees. Van den Heever se styl sal waarskynlik 'n bietjie swaar val op die oog en oor van hedendaagse lesers. Daar is tans soveel opwindende kontemporêre ellendes wat so vermaaklik aangebied word, dat dit slegs toegewyde lesers is wat 'n skrywer soos Van den Heever se werk weer opdiep om te lees. Juis daarom is die 100ste herdenking van die geboortejaar van Van den Heever sekerlik 'n gepaste moment om weer 'n slag bestek te neem van die nalatenskap van hierdie eens so hoog geagte skrywer in Afrikaans.

\section{Die oordele oor van den Heever se werk}

As 'n mens weer gaan lees wat die kritici en letterkundiges oor Van den Heever se werk geskryf het, is dit opvallend dat sekere eienskappe by herhaling aangetoon en beklemtoon word. Die belangrikste hiervan is die beperkte tematiek waarmee hy hom besiggehou het, die feit dat dieselfde temas hoe later hoe duideliker gemanifesteer het omdat die later prosawerke heelwat van die vroeër werk se tematiek herhaal. Die voorliefde vir tipies romantiese temas soos die dood, "verganklikheid, twyfel, verlange en eensaamheid" (Kannemeyer, 1978:3000) verleen aan sy werk 'n erns wat dikwels as swaarmoedig en selfs pessimisties beskou word (Kannemeyer, 1978:301; vgl. ook Van der Elst, 1988 en Van Heerden, 1973). Verder word Van den Heever se styl, die woordeskat en toonaard en veral die neiging om in vae bespiegelinge op te gaan, ook as kenmerkend beskou (Dekker, 1960: 199-200; Van Coller, 1987:42-43; Du Plooy, 1999:653-664). Dit is waarskynlik juis vanweë hierdie eienskappe dat kontemporêre lesers nie meer so maklik vat kry aan Van den Heever se werk nie.

Wat moet hieruit afgelei word? Is dit onvermydelik dat 'n skrywer gewoon vergeet word na sy dood of dat hy later nie meer geag word nie vanweë die tekortkominge in sy werk? Is voortreflikheid die enigste rede waarom 'n skrywer onthou word en indien wel, hoe word daar besluit oor die maatstaf vir voortreflikheid? Is die sterkpunte en swakpunte in ouer literêre werke al waarom dit gaan, of kan literêre werke ook beskou word as insiggewende tydsdokumente vanweë hulle vermoë om as 'n spieël van 'n historiese periode te funksioneer? 'n Ander belangrike vraag is myns insiens of dit wat in 'n hele oeuvre te dikwels voorkom, noodwendig in die enkelwerk ' $n$ probleem is?

Wanneer 'n mens Van den Heever se eie uitsprake oor sy werk nalees, blyk dit dat hy juis oor sake wat met bogenoemde eienskappe verband hou, nagedink het en daarmee geworstel het. In 'n essay "Agtergrond van eie werk", wat verskyn in Afrikaanse skrywers aan die woord 
(Nienaber, 1947:170-188), skryf Van den Heever uitvoerig oor sowel tematiek as styl en toonaard in sy eie werk.

\section{Van den Heever oor sy eie werk}

Die kernargumente van hierdie poëtikale essay verdien nadere aandag omdat dit telkens in verband gebring kan word met wat in Van den Heever se kreatiewe werk na vore kom en ook met wat in die kritiek oor Van den Heever se werk gesê is en word.

\subsection{Terugkeer na vroegste herinnering}

Die essay begin met ' $n$ stelling van nederigheid en Van den Heever verwys na die ongemak waarmee 'n skrywer oor sy eie werk praat, onder meer as gevolg van die feit dat lesers dikwels ander dinge raaksien as wat die skrywer bedoel het. Hy skryf daarna oor die bronne waaruit die skrywer put. Hy begin deur te verwys na die belangrikheid van die vroegste herinneringe wat 'n mens uit jou kinderjare saamdra:

Vir elke mens, en veral vir die skrywer, is dit nodig dat hy moet terugkeer na sy vroegste herinneringe om daar, in die skemerwêreld waar die assosiasies geweef word, nie alleen ryk stof vir sy skryfwerk te vind nie, maar om tewens die nodige verklaring vir baie latere handelinge te ontdek en om op dié wyse sy ontwikkeling teen die regte agtergrond te sien (Van den Heever, 1947:172).

Hy noem dan eksplisiet die plaaslewe en die veranderinge wat met verstedeliking gepaard gaan as sake wat hom diep aangegryp het. Verder is dit duidelik hoe belangrik die natuur vir hom is as die wyer omgewing waarvan hy homself deel voel: "... ver teen die agtergrond van eie lewe ... die vlaktes, berge en riviere” (Van den Heever, 1947:173).

Van den Heever se eerste vyf prosawerke handel hoofsaaklik oor die omstandighede van bepaalde karakters op boereplase en hy maak daarin gebruik van die wêreld wat hy uit sy eie jeug goed ken, dié van die plaas en minder gegoede Afrikaanse mense. Die verhale handel oor die spesifieke probleme waarmee hierdie mense in die eerste dekades van die twintigste eeu te make gehad het. In Op die plaas (1935 [1927]) gaan dit oor die onbeantwoorde liefde van 'n sukkelende jong man met 'n plaasagtergrond vir 'n stadsmeisie. Langs die grootpad (1928) handel oor 'n boer, 'n oorheersende vaderfiguur, en die lotgevalle van sy kinders en familie en in Droogte (1930) word die stryd van vyf broers teen die vernietigende Afrika-droogte uitgebeeld. In hierdie roman word die droogte meer as net 'n lewenswerklikheid om te hanteer, dit word ook simbolies van die geestelike verdorring van die karakters. In Groei (1933) word die plaaslewe voorgestel as die beter leefwyse waarheen 'n 
gesin terugkeer nadat hul lewe in die stad onherroeplik skeef geloop het. In al hierdie romans gaan dit dus om 'n uitbeelding van die landelike boerelewe en sekere verteenwoordigende aspekte van die lewe van Afrikaanse mense. Uit die titels self spreek die bemoeienis met die landelike lewe duidelik en elke titel kan gesien word as 'n metafoor, omdat nie net 'n saak benoem word nie, maar omdat dit in elke geval juis gaan om die betekenis van die fisiese dinge vir die mens se lewe op metafisiese vlak.

In Van den Heever se later werk en ook in sy kortverhale en novelles, speel die stadslewe en die probleme van ontwortelde mense in die stad 'n belangrike rol, benewens die voortgesette temas van die boerelewe, armoede en die mens as slagoffer van die noodlot. Met hierdie temas, die plaaslewe, die stadslewe en menseverhoudinge, bly die skrywer hom dwarsdeur sy skrywersloopbaan bemoei.

Die ses romans wat na 1940 verskyn, het mindere statuur as dié van tussen 1935 en 1939 en heelwat van sy later werk is herhalings en bewerkings van temas wat vroeër reeds gebruik is (Kannemeyer, 1978: 308; Du Plooy, 1999:661). Sommige van die karakters en situasies oortuig nie in dieselfde mate as sterker figure soos Henning en oom Sybrand in vroeër werke nie, maar tematies is die band tussen die vroeë en later werk onmiskenbaar.

Dit blyk dus uit Van den Heever se eie opmerkings sowel as uit sy werk dat die boerelewe, armoede en die mens as slagoffer van die noodlot aanvanklik en later die stadslewe en menseverhoudinge die temas is wat Van den Heever boei en interesseer. Dit is egter duidelik dat hy self goed geweet het waarmee hy hom besig hou en dat hy inderdaad juis daarmee besig wou wees. Dit gaan om 'n bewuste keuse, miskien selfs om 'n soort verantwoordelikheid om te skryf oor wat tydgenootlike mense ervaar. Die sosiale gerigtheid en verantwoordelikheid van Van den Heever se werk kan daarom nie misgekyk word nie en dit is inderdaad 'n vorm van betrokke literatuur waarin stem gegee word aan mense wie se swaarkry byna as vanselfsprekend en as alledaags beskou is.

\subsection{Realisme en romantiek}

Die noukeurige waarneming van die omringende wêreld is vir Van den Heever vanselfsprekend een van die vermoëns wat 'n jeug op die plaas en in die natuur meebring (Van den Heever, 1947:73). Hy praat van sy liefde "vir besonderhede" en beskou dit as essensieel dat 'n skrywer, net soos 'n skilder, sy oë goed moet kan gebruik: "So kom hy (die skrywer $\mathrm{HdP}$ ) deur die werklikheid, en nie deur boeke nie, by die kuns" (Van den Heever,1947:173). 
Die openingstoneel in Laat Vrugte (1987 [1935]) word dikwels as een van die sterkste passasies in Van den Heever se prosa-oeuvre beskryf (Van Coller, 1987:15, 23). Dit is 'n dramatiese toneel waarin oom Sybrand en Henning 'n perd inbreek. Aanvanklik gooi die perd albei af. Uiteindelik breek Henning die perd in, maar oom Sybrand se trots is gekrenk en hy voel dat sy gesag en status deur die val aangetas is. Die beskrywing is dinamies en lewendig en die atmosfeer van opwinding en spanning word baie effektief uitgebeeld.

Die perde trap verskrik en senuweeagtig oor die misblad van die groot klipkraal rond: Hulle neusgate is wyd oop van die opwinding en die bene span sterk en styf bo die pote, wat gaan staan, weer voortkletter, blink strepe maak oor die mis en nou en dan skop dat 'n dowwe hou teen sagte perdevleis gehoor word. ... Nader en nader loop Henning met stadige meettreë, die vangstok skuins langs hom uit, sy oë vas in die vurige, agterdogtige glansing van die vosbles se oë, wat sy kop hoog oplig, vorstelik, uitdagend, terwyl die vel van sy atletiese, gladde lyf bewerig ruk (Van den Heever, 1987:1).

Van den Heever (1947:173-174) skryf in sy opstel dat waarneming alleen nie genoeg is nie, want die skrywer se taak is om dinge in taal weer te gee en daarom moet die skrywer die taal wat sy instrument is, baie goed ken, veral soos dit deur ongekunstelde mense gepraat word. Sy opmerkings oor die taal gaan oor in 'n verduideliking van hoe moeilik dit vir hom is om die balans te vind tussen verstaanbare taal en die persoonlike styl wat groei uit die skrywer se artistieke aanvoeling. Hy haal Bergson aan om die saak nader toe te lig:

Ons waarnemings, gewaarwordinge en begrippe doen hulle van twee kante aan ons voor - die een skerp omlyn, maar onpersoonlik: die ander vaag, in die hoogste mate veranderlik en onuitspreeklik ... Die skerp omlynde term, die saaklike woord, wat uitdruk wat daar vas, algemeen en bygevolg onpersoonlik in die indrukke van mense is, vernietig of oordek ten minste die fyner vlugtige indrukke van ons persoonlike bewussyn (Van den Heever, 1947:175).

Hy verwys verder na Nietzsche se siening dat vir die kunstenaar "die vorm" die saak self word en dat die toenemende vormdrif die kunstenaar van sy medemens vervreem.

Die meeste kontemporêre kenners van die literatuur sal nie saamstem met Van den Heever se waardering vir die vae kreatiewe woord nie, omdat die gebruik van die skerp eenvoudige woord tans juis beskou word as stilisties sterk en omdat die onderskeid tussen artistieke skryfwerk en nie-artistieke skryfwerk tans anders uitval. Nogtans is dit betekenisvol dat Van den Heever die saak so duidelik aan die orde stel 
as 'n probleem in sy skryfaktiwiteit. Hy is bewus daarvan dat die skerpkantigheid van realistiese uitbeelding, wat vir hom belangrik is, en die mymerende besinning oor die betekenis en sin van die reële werklikhede moeilik te versoen is en hy kry dit inderdaad nie reg om die probleem van hierdie tweeledigheid op te los nie.

Die kritici is dit eens dat Van den Heever se werke byna deurgaans 'n neiging toon om gedagtes in vae bespiegelinge en woordoordaad te laat vervloei (Du Plooy, 1999:662). So 'n duidelike kenmerk karakteriseer wel 'n skrywer se werk as eiesoortig, maar as die karakteristieke oorheersend word, word dit ook 'n tekortkoming en 'n teken dat vernuwing en dinamiek ontbreek (Van Heerden, 1973:349).

Hierdie stilistiese problematiek hang saam met die ander sterk eienskap van Van den Heever se werk, naamlik die spanning tussen realisme en romantiek, soos wat dit deur verskillende literatore beskryf is (vgl. veral Minnaar, 1966). Myns insiens gaan dit nie om die feit van die spanning tussen realisme en romantiek in die tekste nie, maar eerder om die onvermoë van die skrywer om hierdie spanning effektief te gebruik. Die tekortkoming spreek des te duideliker as 'n mens in ag neem hoe suksesvol Van den Heever is wanneer hy 'n sterk dramatiese stelling maak soos byvoorbeeld in die gedig "Die gevalle Zoeloe-indoena".

Jou lyf glim soos koper op die veld

en grassaad buig oor jou

hul moredou,

hier waar jy slaap

jou laaste slaap.

As die indoenas weer gaan veg,

die bulte lewe van hul wilde dans,

die skilde kletter en asgaaie blits

hoog in die son

dan slaap jy nog,

dan slaap jy diep,

jou vere wyd verstrooi deur son en reën,

jou lyf wat sag geglim het net soos koper,

dan weg, en jy?

Die grassaad sal nog buig,

die beeste bulk, die lewe roep,

maar jy?

Hier waar jy was, sal skape wei.

Meer dikwels gaan Van den Heever se beskrywings egter oor in vae mymering, veral in die gedigte. Daar is duidelik 'n groot sensitiwiteit in die waarneming en verwoording, maar daar is in die meeste verse 'n 
ondertoon van weemoed en 'n strewe na onkenbare en onbereikbare dinge. In sy later werk het hierdie eienskappe ooropvallend en voorspelbaar geword. Hoewel hy probeer het om die swewende aard, die "newelagtigheid en verglyding" (Kannemeyer, 1978:308) van sy verse teen te werk met vormvastheid in Honderd sonnette (1955), slaag dit nogtans nie heeltemal nie.

In die sonnette bly die digter steeds besig met dinge wat ver is ("Ver lê die kringe van die more-see [...]" - LIII - Van den Heever, 1955:63), wat swewend is, ("Ons voel nou swewend soos die helder lig / en het ver bo die aarde uitgestyg [...]" - LVIII - Van den Heever, 1955:68), wat wyd en groots is ("Die dae is so groots en wit en stil [...]"LII - Van den Heever, 1955: 62; "Die reën blink wit hier voor my in die nag / en rondom suis die wye, eentonige lied [...]" - LX - Van den Heever, 1955:70). Hy soek steeds na die verborge sin agter die dinge met intense gevoeligheid en inlewing aangesien alles vir hom in die teken van verganklikheid staan ("want in die koperglans van najaarskleure / tril die verdoemenis van ou gebeure [...]" - LII - Van den Heever, 1955:62; "So waai die eerste blom bly in die wind, / al is sy wortels in die dood te vind [...]" - LIII - Van den Heever, 1955:63; "Maar straks weet hy hoe elke band vergaan / en hoe hy eensaam in die reënnag staan" - LX - Van den Heever, 1955:70; "Want teen die vergetelheid se diepe slaap / verset die mens hom soos 'n vaakloom kind [...]" - LXXI - Van den Heever, 1955:82).

'n Sonnet soos "Die wasige beeld" (Van den Heever, 1955:83) vertoon die tipiese eienskappe van Van den Heever se digterskap baie duidelik:

Die bloekombome blink nou na die reën en in die lug hang hulle skerp-soet geure, die doringbome dra geel, donsige kleure en newels sluier oor die berge heen ...

Nog altyd was die lewe soos 'n droom, 'n droom waarin die dinge dof verskyn, veel dieper lê die wese, klaar omlyn, veel dieper skuil die kringloop en die stroom.

Dieselfde verskynsel kom voor in die prosatekste. Die novelle Somer (1935), wat as gevolg van die verfilming daarvan seker die bekendste van Van den Heever se prosawerke is, is 'n verhaal wat die lewe op 'n boereplaas in verskillende fasette uitbeeld.

Die plaasagtergrond word uiters realisties beskryf, maar die prosesse en siklusse in die natuur word simbolies deel van die tema van die onontkombaarheid van verganklikheid en die kortstondigheid van skoonheid en geluk. Daar is dus weer die romantisering van die belewenis van 
die natuur, hier juis in die volheid van oestyd, teenoor die realistiese uitbeelding van die karakters se stryd teen die elemente en teen die rykes wat hulle grond wil inpalm. Die romantiese ondertoon word versterk deur die uitbeelding van Wynand as romantiese figuur, as die ewige swerwer.

Laat vrugte wat in 1939 verskyn en beskou word as die hoogtepunt van C.M. van den Heever se prosakuns, vertoon dieselfde wisseling tussen realistiese beskrywing en bespiegelinge oor die mens se plek en rol in die grootse opset van die heelal en in die voortgang van die tyd. Die verhaal gaan oor die erfreg van kinders teenoor die lewensreg van ouerwordende ouers, die stryd tussen die gevestigde volwasse vader en sy sterker wordende en ontwikkelende jong seun, die huweliksongeluk waarin mense vasgevang sit op afgesonderde plase, die onmin tussen bure oor water en grense, familietwiste wat verband hou met rykdom en eiendom en die kleinlike plattelandse onbegrip en vergeldingsgesindheid teenoor die teenspoed van ander (vgl. Du Plooy, 1981).

Vir die tydgenootlike lesers was die rustige byna negentiende-eeuse verteltrant nie 'n probleem nie, maar vir die laat twintigste-eeuse leser is die uitweidings en onderbrekings en veral die bespiegelende, soms byna prekerige toon daarvan iets wat afbreuk doen aan die roman.

Laat vrugte word uiteindelik 'n breedopgesette uitwerk van die tema van verganklikheid, spesifiek in dié sin dat die mens sy plek in die groot opset van die Skepping moet aanvaar en dat hy moet begryp dat die individu 'n klein plekkie vul en 'n enkele lewensiklus voltooi teen die agtergrond van die onstuitbare en ewige gang van tyd. Hierdie tema word beklemtoon deur die gebeure te plaas teen die grootsheid van die landskap. Die beskrywinge van die landskap is sodanig dat die klein plek wat die mens inneem, duidelik word. So staan Johanna na die sterre en kyk wanneer sy absoluut alleen en verlate voel en oom Sybrand staan onder die "koninklike gestaltes" van die populiere om sy nietigheid te beklemtoon. Die verhaal en karakters word meer as net die vertel van 'n verhaal; dit gaan primêr om die uitbeelding van die tema dat die mens en sy strewes altyd ondergeskik staan aan groter magte en die ewige patroonmatige van die natuur soos deur God beskik.

\subsection{Pessimisme en godsdienstige opvattinge}

Wanneer van den Heever in sy opstel oor eie werk skryf oor wat die natuur vir hom beteken, sê hy: "En dan, naas hierdie vryheid in die natuur, die somber, temperende krag van die godsdiens! Dit was asof ' $n$ mens tussen vryheid en tug beweeg!" (Van den Heever, 1947:173). 
Die siening van godsdiens as iets beklemmends of neerdrukkends kom na vore in heelparty van Van den Heever se gedigte. In die sonnet "Misverstand" (Van den Heever, 1955:74) voel die digter dat " (a)s ons in ons allenigheid verstaan/ hoe diep ons in 'n wildernis verkeer ... dan voel ons diep geskend en wreed gekul". Die onbegrip en magteloosheid teenoor magte bo en buite die mens, word selfs as verwerping ervaar (Van den Heever, 1955:83):

En ek het, aardgebonde, deur die tyd die beeld sien lig van ons verworpenheid.

Dit lyk asof Van den Heever die mens sien as uitgelewer aan die nietigheid, meer nog, aan die besef van sy eie kleinheid. Dit is asof die skrywer dink dat dit vir die mens onmoontlik is om sy geestelike vermoëns te verwerklik binne die beperkinge van die menslike kondisie. Nogtans is daar nie 'n verwoording van openlike opstandigheid in die gedigte nie. Die peiling van die verborge diepere sin van menslike ervaring word nooit finaal afgehandel nie en Van den Heever se bespiegelinge eindig telkens weer met 'n religieuse aanvaarding van die voortgang van die groot ritmiese siklusse van die heelal as die patroon van die skepping van God ("Musiek", Versamelde gedigte):

So het ek diep geluister hoe wêrelde in wêrelde vloei en kring en God deur alles as ritme sy hoogste himne sing.

Die voortdurende besinning in Van den Heever se verse en romans en verhale lei onteenseglik tot 'n donker en pessimistiese siening van die lewe in al sy fasette en al die temas in Van den Heever se werk word inderdaad deur 'n relatief donker bril beskou (vgl. Kannemeyer, 1978: 301; Van den Elst, 1988; Van Heerden, 1973). Daar is aangetoon dat Van den Heever se kunstenaarskap en die onderliggende waardesisteem waaruit sy werk groei, bepaal word deur die historiese omstandighede van sy lewe (die neerdrukkende tyd net na die AngloBoereoorlog) en sy opvattinge oor religie en politiek (Van der Elst, 1988). Hy ontgroei die somberheid van die na-oorlogse sfeer nooit werklik nie. Maar ten spyte daarvan dat hy lewe in 'n tyd van politieke woelinge, hou Van den Heever hom nie met die georganiseerde politiek en politieke stelsel besig nie. Hy bly die denker wat as skrywer die werklikheid onder woorde bring en probeer in perspektief plaas, maar sy donker siening oorheers telkens die slotsom wat bereik word.

Volgens Dekker (1960:199) het Van den Heever in die breë beskou wel sy Christelike opvattings behou, maar nie meer in die vaste Calvinistiese vorm nie. Hy was onder meer sterk beïnvloed deur die pessimisme van Schopenhauer en ook deur die denksisteem van Spinoza. In al sy my- 
meringe waarin religieuse aanvaarding teenoor 'n soort opstandigheid oor die beperkinge van die menslike bestaan te staan kom, ontwikkel die magteloosheid tot 'n diepliggende pessimisme in sy werk.

My denke is gekerker in 'n baan

wat deur die alledaagse dinge strek

en my, wat hoog die graal van drome dra,

neerskadu in 'n duister aardse plek [...]

("Die gevangenis", Aardse vlam)

As 'n mens die uitsprake van die literêre kritiek en Van den Heever se eie opmerkings oor godsdiens in die essay uit 1947 bekyk en dit in verband bring met die inhoud van die verse en romans, dan kom daar ook hier 'n duidelike tweeledigheid na vore. Enersyds sien Van den Heever godsdiens as 'n vorm van tug (Van den Heever, 1947:173) en veral in die poësie is daar verwysings na die mens as "verworpe", "geskend", "gekul" sodat die mens magteloos en eensaam staan teenoor die groot magte van die natuur soos geskape deur God. Aan die ander kant verklaar Van den Heever ook herhaaldelik sy onderworpenheid aan juis hierdie bo-menslike magte en aan God.

Daar sou gevra kon word of Van den Heever se pessimisme en die donker en negatiewe siening van die menslike lot, nie voortvloei uit 'n onderdrukte of onverwerkte spanning tussen frustrasie met die menslike beperkinge aan die een kant en die belydenis van 'n religieuse oortuiging wat aanvaarding eis aan die ander kant nie.

\subsection{Van den Heever se siening van kunstenaarskap}

In die verskillende kunsvorme lei 'n spanning tussen onversoenbaarhede dikwels tot 'n interne dinamiek wat as die kragbron van die kunswerk dien, maar by Van den Heever is die tweeledigheid telkens opvallender as die bindende spanning wat daaruit sou kon groei (Dekker, 1960:207209; Van Heerden, 1973:352; Opperman, 1953:159). In aansluiting hierby is dit opmerklik dat Van den Heever die filosoof Kierkegaard aanhaal om die aard en rol van die kunstenaar en sy geestelike ingesteldheid te beskryf. Na aanleiding van die vraag wie 'n digter is, skryf Kierkegaard soos volg (Van den Heever, 1947:177):

'n Ongelukkige mens wat diep folteringe in sy hart verberg, maar wie se lippe so gevorm is dat as 'n kreun of 'n kreet ontsnap, dan klink dit soos lieflike musiek ... en mense drom om die digter saam en sê aan hom: 'Sing nogeens - dadelik!' - wat dieselfde is om te sê: mag nuwe folteringe jou siel tref en mag jou lippe gevorm bly soos hulle was, want 'n kreet sou ons pynig, maar die musiek is heerlik. 
Die aanhaling van Kierkegaard verwys verder na die plek en rol van die resensent in die kuns:

En die resensente staan nader en sê: 'Dit is presies reg, net soos dit volgens die reëls van die estetika moet wees!' Wel, natuurlik: 'n resensent kom op 'n haar ooreen met 'n digter - behalwe dat hy geen folteringe in sy siel het nie en geen musiek op sy lippe nie (Van den Heever, 1947:177).

Van den Heever se kommentaar op hierdie aanhaling is dan dat dit begryplik is dat kunstenaars se lewens nie maklik is nie en hy sê ook eksplisiet dat skryf vir hom ook nie lekker of maklik is nie:

Daar is skrywers wat beweer dat die skrywe van gedigte vir hulle 'n louter vreugde is, daar is diegene wat groot genoeë vind in skrywe. Ek kan alleen sê dat ek hulle beny. Vir my het dit nie baie genoeë gebring nie, en ek moet eerlik sê dat ek die verheerliking van die kuns, wat teen so 'n prys gekoop word, as oordrewe aanvoel (Van den Heever, 1947:177).

Dit is merkwaardig dat Van den Heever, ten spyte van hierdie "swaar" siening van skryf, so 'n produktiewe skrywer was. In 'n gesprek (in Junie 2002) het C.M. van den Heever se dogter, mev. Salome Herbst, aan my gesê dat haar vader onvermoeid geskryf het, dat dit vir hom soos 'n dure verantwoordelikheid was en dat hy deurgaans uitermate hard gewerk het. Sy het bygevoeg dat Van den Heever in sy daaglikse lewe nie 'n somber mens was nie en dat sy gesinslede hom nie as pessimisties ervaar het nie, al word sy werk so gelees.

Dit wil dus voorkom asof skryf vir Van den Heever terselfdertyd las en bevryding was en asof 'n soortgelyke dualiteit as dié wat tematies in sy werk voorkom, ook sy ervaring van skrywerskap as sodanig gekenmerk het.

\subsection{Die ware vryheid moet na wette luister}

Van den Heever skryf uitvoerig oor bepaalde tegniese aspekte van die skryfproses en stel duidelik dat verhaalstof op sigself nooit deurslaggewend is nie, maar dat die inwerking van die kunstenaar se gees op dit waaroor hy skryf, bepalend is. Vir hom is die etiese die ondergrond wat die estetiese ewewig tussen vorm en inhoud herstel (Van den Heever, 1947:176). Hierdie ewewig is afhanklik van die inwerking van die geestelike inhoude van die kunstenaar en hierdie inhoude dui inderwaarheid op die kunstenaar se lewens- en wêreldbeskouing. Die kunstenaar se visie op die werklikheid word beïnvloed deur die omstandighede waarin hy lewe en werk aangesien die "kunstenaar en mens, kuns en lewe" nie 
geskei kan word nie. Die skrywer dink groot en vry, maar word beperk deur oortuiginge en verantwoordelikhede: "Sy vryheid as kunstenaar word deur diep gebondenhede getemper" (Van den Heever, 1947:180).

Dit beteken enersyds dat die kunstenaar nie los staan van sy volk en die kontemporêre werklikhede nie, maar andersyds ook dat die kunstenaar wyer moet kyk. Van den Heever self was deeglik belese in die geskiedenis en filosofie. Dit was vir hom essensieel dat die prosaskrywer die mens sal leer ken, maar ook in staat sal wees om krities na mense te kyk. Daarom was intellektuele dissipline vir hom baie belangrik en hy haal Pascal aan wat gesê het dat al die mens se waardigheid in sy denke lê. Dit het Van den Heever inderdaad beoefen deur deurlopend ernstig na te dink en besinnend om te gaan met die onderwerpe en temas en mense in sy romans, verhale en gedigte.

Die spanning tussen vryheid en vorm, net soos die spanning tussen romantiek en realisme en die spanning tussen die hoë strewe van die mens en die aardse beperkinge is uiteindelik, so wil dit voorkom, nie net bepalend vir die literêre inhoud en styl nie, maar geld ook Van den Heever se skrywerskap en uiteindelik ook sy belewenis as mens.

\section{Hoe kan Van den Heever en sy werk beskou word, anno 2003?}

Die slotsom van die literêre kritiek van die afgelope 30 jaar is dat die mees kenmerkende eienskappe van C.M. van den Heever se oeuvre die beperkte tematiek, die somber ingesteldheid en 'n eenselwigheid van styl en toon is.

Ernst van Heerden (1973:352) maak die volgende konkluderende uitspraak oor Van den Heever se poësie:

Wat is ' $n$ mens se slotoordeel oor C.M. van den Heever as digter? Sy voorliefde vir 'coma'-woorde en die gebrek aan konkreetheid is deurgaans 'n groot tekortkoming. Vaagheid omnewel en versluier alles en die leser kry telkens die indruk dat, alhoewel die woorde 'n sekere sin inhou, die werklike betekenis en bedoeling êrens agter die woorde lê. Sy kennelike strewe, soms na 'n monumentale struktuur, soms na 'n magistrale lyn, het in die omraming van wat genoem is sy 'romanties-realistiese tweeslagtigheid', net 'n strewe gebly.

Wat die prosa betref, gee die kritici oor dekades heen baie aandag aan die botsende elemente van romantiek en realisme in die verhale en beskou die sterk liriese inslag as 'n belemmering van die ideaal van grootse epiek (vgl. Dekker, 1934, 1960, 1964; Schoonees in Nienaber, 
1959; Malherbe, 1940, 1948; Mulder, 1942). Die meeste kritici beklemtoon die tweeslagtigheid in Van den Heever se prosa en wys telkens op die onvermoë om die teenstrydighede tussen die stoflike en geestelike, die mooie en lelike, die realiteit en fantasie, romantiese ontvlugting en werklikheidsgetrouheid te versoen of te integreer (vgl. Minnaar, 1966). Daarby kom dat Van den Heever se voorliefde vir lang filosofiese uitweidings en lang beskrywings wat stemming moet skep, dikwels as onfunksioneel, langdradig en selfs as mooiskrywery gekritiseer word.

Uit 'n sekere hoek gesien, is heelwat van hierdie kritiek natuurlik self tydgebonde. Waarom mag realisme en romantiek nie vermeng word nie? Dit kan immers juis gaan om die onversoenbaarheid in belewenis van twee ingesteldhede teenoor die lewe wat in spanning tot mekaar staan. Waarom moet epiek realisties wees? Waarom is 'n romantiese lewensgevoel 'n tekortkoming? Waarom moet die polarisasie tussen stad en platteland as 't ware dokumentêr korrek uitgebeeld word as die skrywer sterk menings na die een of ander kant het? (vgl. Du Plooy, 1999:662663).

In hierdie artikel word betoog dat Van den Heever self deeglik bewus was van alles wat in die kritiek as tekortkominge genoem word, maar dat dit vir hom juis die kern van sy skrywersproblematiek was. Hy was hom bewus van al die genoemde kwessies, hetsy esteties of lewensbeskoulik van aard, maar meer nog, hy het hom eksplisiet juis daarmee besiggehou in sy nadenke oor sy werk en sy skrywerskap. Van sy voorkeur vir 'n spesifieke soort denke en lewensuitkyk en van die stilistiese probleme wat daaruit voortvloei gee hy openlik rekenskap in sy essay oor eie werk (Nienaber, 1947:179-188).

Daar kan gevra word in watter mate Van den Heever se standpunte en opvattings en lewensuitkyk gesien sou kon word as verteenwoordigend van 'n denkpatroon wat tipies was van sy tyd? Daar sou geredeneer kon word dat, met tekortkominge en al, Van den Heever se werk dui op belangrike aksente en ingesteldhede van die tyd waarin hy gelewe het sodat die stilistiese en artistieke tekortkominge as 'n vorm van lewensgetrouheid (spesifiek wat lewensbeskouing betref) gesien sou kon word.

Maar dan moet 'n mens toegee dat Van den Heever se werk dateer het, dat dit selfs moeilik is om sommige van die werke nou te lees. Myns insiens is die redes waarmee die kritiek gemotiveer word, nie ongekwalifiseerd geldig nie, maar die feit dat die werk tekortkominge het, bly waar. C.M. van den Heever het eenvoudig nie oor die verhaaltegniese en poëtiese vermoëns beskik om die grootsheid van sy artistieke strewes te laat realiseer nie. Hy wou groot dink, hy het op sensitiewe wyse die swewende sin van dinge agter die werklikheidsverskynsels aangevoel, 
maar dit is nie vir alle skrywers beskore om hierdie aanvoeling tot artistieke gestalte te laat kom nie. Interessant genoeg is die pessimistiese lewensiening, die gevoel van onmag teenoor die gang van die natuur, die bewustheid van 'n onvermoë om te begryp en te aanvaar en veral 'n bewustheid van die afwesigheid van absoluuthede verwant aan die relativisme, 'n ingesteldheid wat hier nader aan die einde van die twintigste eeu baie sterker is as in Van den Heever se eie leeftyd.

Dit bly belangrik dat veral Van den Heever se prosawerke belangrike insigte bevat oor die lewensomstandighede en ook aspekte van die tydsgees waarin dit geskryf is. Die romans en verhale beeld verskillende fases in die geskiedenis van die Suid-Afrikaanse gemeenskap uit, soms uit vorige eras en soms tydgenootlik. Ek is oortuig daarvan dat 'n studie van hierdie tekste met die oog daarop om die onderliggende denkpatrone van die karakters as mense van hulle tyd en die lewensomstandighede van mense op bepaalde momente in die geskiedenis te ondersoek, interessante sosiologiese, ideologiese en selfs religieuse inligting sal oplewer. As tydsdokumente is hierdie oeuvre gewis nog nie na behore ontgin nie (Du Plooy, 1999:664).

\section{Slotsom}

C.M. van den Heever bly 'n belangrike figuur in die Afrikaanse literatuur van die eerste helfte van die twintigste eeu. Sy oeuvre bevat sterk hoogtepunte en vanselfsprekend ook werk van mindere gehalte, maar in vele opsigte het hierdie werk ' $n$ belangrike rol gespeel in die ontwikkeling van die literatuur wat daarop gevolg het. In sy werk het temas soos die kosmiese bewussyn en literêre vorme soos die plaasroman beslag gekry, en waar dit eers as norm gesien is, het dit later as teëpool gedien vir vele gedigte en romans wat juis téén die stereotiepe vorm in geskryf is. Saam met ander skrywers uit die dertigerjare vul C.M. van den Heever dus 'n belangrike plek in die historiese ontwikkeling van die Afrikaanse literatuur.

Wat egter belangrik is, is dat herlesing van die werk van ouer skrywers nuwe insigte en nuwe fasette van die literêre werke bewerkstellig en moontlik maak. Nie net kan 'n mens die verlede beter verstaan deur die literatuur uit vroeëre tydperke te lees nie, maar kennis van die verlede kan help om die hede beter te verstaan, esteties en ideologies en sosiologies gesproke.

Die taak van die toegewyde leser, of eintlik herleser, kan dus nie sterk genoeg beklemtoon word nie. Daar is dimensies van die verlede wat slegs in die literatuur terug te vinde is en deur voortdurende lees en herlees word ' $n$ mens daarvan bewus dat daar, in teenstelling tot Van 
den Heever se donker vooruitskouing van sy nalatenskap, inderdaad beduidende spore in die sand oorbly.

\section{Bibliografie}

Dekker, G. 1934. Causerie en kritiek. Pretoria : Van Schaik.

Dekker, G. 1960. Afrikaanse literatuurgeskiedenis. Kaapstad : Nasionale Boekhandel.

Dekker, G. 1964. Oordeel en besinning. Kaapstad : Human \& Rousseau.

Du Plooy, H.J.G. 1981. Die verhaal in Laat vrugte en 18-44. Pretoria : Universiteit van Pretoria. (M.A.-verhandeling.)

Du Plooy, Heilna. 1999. C.M. van den Heever. In: Van Coller H.P. (red.) Perspektief en profiel. Pretoria : Van Schaik. p. 653-664.

Kamp, Y. 1953. Christiaan Maurits van den Heever - 'n bibliografie. Skool van Biblioteekwese. Kaapstad : Universiteit van Kaapstad.

Kannemeyer, J.C. 1978. Geskiedenis van die Afrikaanse literatuur, I. Kaapstad : Academica.

Malherbe, F.E.J. 1940. Aspekte van die Afrikaanse literatuur: studies van belangrike werke. Kaapstad : Nasionale Pers.

Malherbe, F.E.J. 1948. Wending en inkeer. Kaapstad : Nasionale Pers.

Minnaar, L.C. 1966. Realisme en romantiek in die prosawerk van C.M. van den Heever. Potchefstroom : PU vir CHO. (D.Litt.-proefskrif.)

Mulder, H.A. 1942. Twee wêrelde: opstelle oor Afrikaanse en Nederlandse letterkunde. Pretoria : Van Schaik.

Nienaber, P.J. (red.) Afrikaanse skrywers aan die woord. Johannesburg : Afrikaanse Pers.

Nienaber, P.J. (red.) 1959. Gedenkboek C.M. van den Heever, 1902-1957. Johannesburg : Afrikaanse Pers.

Nienaber, P.J. (red.) 1973. Perspektief en profiel. Johannesburg : Afrikaanse Pers.

Opperman, D.J. 1953. Digters van Dertig. Johannesburg : Nasionale Boekhandel.

Van Coller, H.P. 1987 [1939]. Laat vrugte. Reuseblokboek. Pretoria : Academica.

Van den Heever, C.M. 1928. Langs die grootpad. Pretoria : Van Schaik.

Van den Heever, C.M. 1930. Droogte. Pretoria : Van Schaik.

Van den Heever, C.M. 1932. Deining. Pretoria : Van Schaik.

Van den Heever, C.M. 1933. Groei. Pretoria: J.L. van Schaik.

Van den Heever, C.M. 1935. Somer. Pretoria : Van Schaik.

Van den Heever, C.M. 1935 [1927]. Op die plaas. Bloemfontein : Nasionale Pers.

Van den Heever, C.M. 1938. Stemmingsure. Pretoria : Van Schaik.

Van den Heever, C.M. 1938. Aardse vlam. Pretoria : Van Schaik.

Van den Heever, C.M. 1946. Woestynsand dek die spore. Johannesburg : Afrikaanse Pers.

Van den Heever, C.M. 1947. Agtergrond van eie werk. In: Nienaber, P.J. (red.) Afrikaanse skrywers aan die woord. Johannesburg: Afrikaanse Pers. p. 170188.

Van den Heever, C.M. 1955. Honderd sonnette. Pretoria : Van Schaik.

Van den Heever, C.M. 1987 [1939]. Laat vrugte. Pretoria : Van Schaik.

Van der Elst, E.A. 1988. Waardesisteem en literêre kommunikasie: 'n teoretiese ondersoek toegepas op prosatekste van C.M. van den Heever en Stijn Streuvels. Potchefstroom : PU vir CHO. (M.A.-verhandeling.)

Van Heerden, E. 1973. C.M. van den Heever. In: Nienaber, P.J. (red.) Perspektief en profiel. Johannesburg : Afrikaanse Pers. p. 349-360. 


\section{Kernbegrippe:}

C.M. Van den Heever

literêre kritiek

ouer Afrikaanse prosa

poëtika

\section{Key concepts:}

Afrikaans fiction 1930-1950

C.M. van den Heever

literary criticism

poetics 